\title{
Influence of the degree of exposure to lead on relations between alcohol consumption and the biological indices of lead exposure: epidemiological study in a lead acid battery factory
}

\author{
C Cezard, C Demarquilly, $M$ Boniface, J M Haguenoer
}

\begin{abstract}
Alcohol has been shown to interact with lead to influence haem biosynthesis. The aim of this study was to define the dependence of this interaction on the degree of exposure to lead. Exposure to alcohol was estimated by measurement of alcohol concentrations in a sample of urine collected during the morning (AlcUM) (0.82 (SD 4.36) $\mathrm{mmol} / \mathrm{l})$ and in a sample collected during the afternoon (AlcUA) (1.15 (SD 3.49) mmol/1). The biological monitoring of exposure to lead included measurements of blood lead (Pb-B) (1.82 (SD $0 \cdot 72) \mu \mathrm{mol} / 1)$, urinary $\delta$-aminolaevulinic acid (ALAU) (35.33 (SD 28.00) $\mu \mathrm{mol} / \mathrm{l}$; d = 1.015), and erythrocyte zinc-protoporphyrin (ZPP) (112.90 (SD 83.71) $\mathrm{nmol} / \mathrm{mmol} \mathrm{Hb}$ ) concentrations. The study of the influence of the degree of occupational exposure to lead on relations between alcohol consumption and effects of the exposure to lead led to the consideration of two different groups-namely, mildly and strongly exposed subjects. In the first group, individual biological susceptibility seemed to play a preponderant part. In the second, the pool of lead present in the body seemed to be sufficiently important to mask the effects of individual susceptibility.
\end{abstract}

Studies about the relations between drinking habits and effects of lead generally consider the influence of alcoholism on parameters of lead absorption. ${ }^{1-12}$

Institut de Médecine du Travail, faculté de Médecine, 1, place de Verdun, 59045 Lille Cédex, France

C Cezard, J M Haguenoer

Laboratoire de Biomathématiques, faculté de Pharmacie, 3, rue du Pr Laguesse, 59045 Lille Cédex, France

C Demarquilly, $M$ Boniface
They indicate an increase in blood lead concentrations in alcoholic subjects. ${ }^{1-9}$

The purpose of this study was to investigate whether the influence of alcohol on parameters of lead poisoning depends upon the degree of exposure to lead.

Materials and methods

Blood and urine samples were obtained from 526 workers of a lead acid battery factory. Blood was collected by venepuncture in Veinoject tubes containing heparin as anticoagulant.

Alcohol concentrations were estimated with a gas chromatographic method in a sample of urine collected in the morning (AlcUM) and a sample collected in the afternoon (AlcUA). Standard solutions were prepared by diluting $100 \mu \mathrm{l}$ of known ethanol concentrations with $900 \mu \mathrm{l}$ water containing $6.69 \mathrm{mmol}$ of propyl alcohol/1.

Urine samples were treated in the same way. A total of $2 \mu \mathrm{l}$ of each mixture was injected into a Varian 1400 gas chromatograph equipped with a Porapak $Q$ column (injector $190^{\circ} \mathrm{C}$, column $190^{\circ} \mathrm{C}$, detector $190^{\circ} \mathrm{C}$, carrier gas nitrogen). Urinary alcohol concentrations were calculated by comparing the quotients of area of the ethanol/area of the propyl alcohol peaks of urine samples with those of standard solutions.

The following indices of lead poisoning were estimated: (1) index of lead absorption: blood lead concentration $(\mathrm{Pb}-\mathrm{B})$ determined with an atomic spectrophotometric method with graphite furnace and Zeeman non-specific absorption correction after extraction of blood lead by pyrrolidine dithiocarbamate (ammonium salt) and methyl isobutyl ketone. ${ }^{1314}$

(2) Indices of lead effects on haem biosynthesis: (a) urinary $\delta$-aminolaevulinic acid (ALAU) measured with a colorimetric method..$^{15}$ All reagents were provided by Merck Inc and were analysis grade. 
Table 1 Characteristic values for parameters of alcohol consumption and parameters of exposure to lead

\begin{tabular}{|c|c|c|c|c|c|}
\hline Parameter & $\begin{array}{l}\text { Blood lead } \\
\text { concentrations } \\
(P b-B, \mu m o l / l)\end{array}$ & $\begin{array}{l}\text { Zinc protoporphyrin } \\
\text { concentrations } \\
(Z P P, \text { nmol } / \mathrm{mmol} \mathrm{Hb})\end{array}$ & $\begin{array}{l}\delta \text {-Aminolaevulinic } \\
\text { acid concentrations } \\
(A L A U, \mu m o l / l)\end{array}$ & $\begin{array}{l}\text { Morning urinary } \\
\text { alcohol } \\
\text { concentrations } \\
(\text { AlcUM, mmol/l) }\end{array}$ & $\begin{array}{l}\text { Afternoon urina } \\
\text { alcohol } \\
\text { concentrations } \\
\text { (AlcUA, mmol) }\end{array}$ \\
\hline $\begin{array}{l}\text { Number of subjects } \\
\text { Minimal value } \\
\text { Maximal value } \\
\text { Mean value } \\
\text { Standard deviation } \\
\text { Normal distribution }\end{array}$ & $\begin{array}{c}526 \\
0.14 \\
4 \cdot 99 \\
1 \cdot 82 \\
0.72 \\
\text { Yes }\end{array}$ & $\begin{array}{l}526 \\
17.92 \\
471 \cdot 04 \\
112.90 \\
83 \cdot 71 \\
\text { No }\end{array}$ & $\begin{array}{c}(d=1 \cdot 015) \\
526 \\
3 \cdot 82 \\
301.39 \\
35 \cdot 33 \\
28 \\
\text { No }^{28}\end{array}$ & $\begin{array}{l}526 \\
0 \\
51 \cdot 63 \\
0 \cdot 82 \\
4 \cdot 36 \\
\text { No }^{2}\end{array}$ & $\begin{array}{l}526 \\
0 \\
28 \cdot 65 \\
1 \cdot 15 \\
3 \cdot 49 \\
\text { No }^{3}\end{array}$ \\
\hline Normal value & $\begin{array}{l}<1.93 \\
\text { (307 subjects) }\end{array}$ & $\begin{array}{l}<76 \cdot 8 \\
\text { (244 subjects) }\end{array}$ & $\begin{array}{l}<45 \cdot 78 \\
\text { (419 subjects) }\end{array}$ & $\begin{array}{c}0 \\
\text { (481 subjects) }\end{array}$ & $\begin{array}{c}0 \\
\text { (423 subjects) }\end{array}$ \\
\hline
\end{tabular}

Concentration of ALAU was corrected for specific gravity. (b) Erythrocyte zinc-protoporphyrin concentration (ZPP) determined with a haematofluorimeter AVIV-ZPP meter. (c) Packed cell volume was measured with a micromethod using calibrated tubes that were centrifugated.

Statistical analysis was with Spearman rank coefficients of correlation and Student's $t$ test.

\section{Results}

Table 1 gives the lowest and highest values found in the population as well as mean value and standard deviation for each parameter concerning alcohol or lead exposure. Low means were found for AlcUM and AlcUA concentrations. This could be explained by the many subjects for whom AlcUM or AlcUA had a null value. Mean values for ALAU and $\mathrm{Pb}-\mathrm{B}$ concentrations were normal whereas ZPP concentration was higher than normal.

Table 2 gives the coefficients of correlation between parameters of alcohol exposure and parameters of lead poisoning for the whole population.

We found a statistically significant (positive) co- efficient of correlation only between $\mathrm{Pb}-\mathrm{B}$ and AlcUM and between ALAU and ALcUA.

Because of the many subjects for whom AlcUM or AlcUA was zero, we also calculated coefficients of correlation between these parameters for two groups: subjects for whom AlcUM was positive and subjects whose AlcUA was positive (table 3 ). Only coefficients of correlation between $\mathrm{Pb}-\mathrm{B}$ and $\mathrm{AlcUA}$ and between ZPP and AlcUM concentrations were statistically significant.

Groups were created among the population according to the concentrations reached by $\mathrm{Pb}-\mathrm{B}$, ALAU, or ZPP and coefficients of correlation were calculated between parameters of alcohol intake and parameters of lead poisoning for each group.

Relations between alcohol intake and lead poisoning were studied in the two subgroups-namely, moderate metal absorption with no or few alterations of haem biosynthesis; and high $\mathrm{Pb}-\mathrm{B}$ values or major disturbances in haem biosynthesis.

In the first subgroup, coefficients of correlation between AlcUM or AlcUA and $\mathrm{Pb}-\mathrm{B}$ were always positive and often statistically significant. Coefficients of correlation between ALAU or ZPP and parameters of alcohol consumption had variable signs.

Table 2 Spearman coefficients of correlation between different parameters of table 1

\begin{tabular}{|c|c|c|c|}
\hline & $\begin{array}{l}\text { Blood lead } \\
\text { concentrations (Pb-B) }\end{array}$ & $\begin{array}{l}\text { Zinc protoporphyrin } \\
\text { concentrations ( } Z P P)\end{array}$ & $\begin{array}{l}\delta \text {-Aminolaevulinic } \\
\text { acid concentrations ( } A L A U)\end{array}$ \\
\hline $\begin{array}{l}\text { Morning urinary alcohol } \\
\text { concentrations (AlcUM) } \\
\text { Afternoon urinary alcohol } \\
\text { concentrations (AlcUA) }\end{array}$ & $\begin{array}{l}r=0.175 \\
p<0.0001 \\
r=0.076 \\
N S\end{array}$ & $\begin{array}{l}r=-0.036 \\
N S \\
r=0.047 \\
N S\end{array}$ & $\begin{array}{l}r=0.060 \\
N S \\
r=0.104 \\
p<0.05\end{array}$ \\
\hline
\end{tabular}

Table 3 Spearman coefficients of correlation between different parameters in workers who had some alcohol in their urine

\begin{tabular}{llll}
\hline & $\begin{array}{l}\text { Blood lead } \\
\text { concentrations }(P b-B)\end{array}$ & $\begin{array}{l}\text { Zinc protoporphyrin } \\
\text { concentrations }(Z P P)\end{array}$ & $\begin{array}{l}\delta \text {-Aminolaevulinic } \\
\text { acid concentrations }(A L A U)\end{array}$ \\
\hline $\begin{array}{l}\text { Morning urinary alcohol } \\
\text { concentrations (AlcUM) }>0\end{array}$ & $\mathrm{r}=0.16$ & $\mathbf{r}=-0.38$ & $\mathbf{r}=-0.20$ \\
$\begin{array}{c}\text { Afternoon urinary alcohol } \\
\text { concentrations (AlcUA) }>0\end{array}$ & $\mathrm{r}=0.24$ & $\mathbf{p}<0.05$ & $\mathrm{NS}$ \\
\hline
\end{tabular}


In the group of subjects with high $\mathrm{Pb}-\mathrm{B}, \mathrm{ALAU}$, or ZPP concentrations, coefficients of correlation were studied. Between $\mathrm{Pb}-\mathrm{B}$ and alcohol ingestion the correlation was mostly positive but often statistically non-significant; parameters of alcohol ingestion and effects of lead on haem biosynthesis showed negative, often statistically significant correlations. An exception to this behaviour was that ALAU and alcohol intake showed inconsistent relations with increased ZPP values.

\section{Discussion}

The study population had a low alcohol intake, which made it difficult to study the effect of alcohol on lead absorption and on the haematological effects of lead. The concentrations of $\mathrm{Pb}-\mathrm{B}$ were also low in workers in this factory, although high enough to result in abnormal ALAU and ZPP values.

Alcohol may increase the absorption of lead in the gastrointestinal tract, ${ }^{69}$ alter its distribution to targets and provoke a mobilisation of lead bound to tissues. $^{2}$ Acetaldehyde formed from alcohol may inhibit $\delta$-aminolaevulinic dehydratase. ${ }^{12616} \mathrm{It}$ is also possible that one effect may neutralise another one. The fact that the signs of coefficients of correlation between ALAU or ZPP and parameters of alcohol ingestion were inconsistent in groups of workers without significant biological effects of lead may be explained by the coexistence of these mechanisms or the lack of interactions at the given exposure concentrations. Even in subjects with obviously disturbed haem synthesis, alcohol intake had little effect on high $\mathrm{Pb}-\mathrm{B}$ values and coefficients of correlation between $\mathrm{Pb}-\mathrm{B}$ and AlcUM or AlcUA were not consistently significant.

Negative trends in correlations between ALAU or ZPP and parameters of alcohol uptake might be explained by the mobilisation of tissue bound lead. In fact, we can hypothesise that, when occupational exposure to lead induces a noticeable increase of $\mathrm{Pb}-\mathrm{B}, \mathrm{ALAU}$, and ZPP concentrations, the amount of mobilised lead may be higher than in subjects with low exposure.

In conclusion, this epidemiological study allowed us to hypothesise on mechanisms that should be verified by further in vitro studies on erythrocytes.
Requests for reprints to: J M Haguenoer, Institut de Médecine du Travail, faculté de Médecine, 1, place de Verdun, 59045 Lille Cédex, France.

1 Secchi GC, Cambiaghi G, Monti M, et al. Alterazioni del metabolismo porfirinico da cause non professionali. Med Lav 1978;69:59-73.

2 Cortona G, Alessio L. Condizioni di iper suscettibilita in soggetti professionalmente esposti a piombo inorganico. Med Lav 1978;69:50-8.

3 Vincent $M$, Vincent $F$, Faure J. Bilan de la teneur en éléments métalliques d'une population représentative du département de l'Isère ( 850 personnes). Concentrations sanguines en plomb, cuivre, zinc et mercure. Etude de facteurs pouvant influencer cette distribution. Bull Méd Lég Toxi 1978;21: 753-8.

4 Grandjean $P$, Olsen NB, Hollnagel H. Influence of smoking and alcohol consumption on blood lead levels. Int Arch Occup Environ Health 1981;48:391-7.

5 Bortoli A, Mattiello G, Zotti S, et al. Blood-lead levels in patients with chronic liver diseases. Int Arch Occup Environ Health 1983;52:49-57.

6 Bortoli A, Fazzin G, Marin V, et al. Relationships between blood lead concentration and aminolevulinic acid dehydratase in alcoholics and workers industrially exposed to lead. Arch Environ Health 1986;41:251-60.

7 Grasmick C, Huel G. The combined effect of tobacco and alcohol consumption on the level of lead and cadmium in blood. $S c i$ Total Environ 1985;41:207-17.

8 Watanabe T, Fujita H, Hoizumi A, et al. Baseline level of blood lead concentration among Japanese farmers. Arch Environ Health 1985;40:170-6.

9 Dally S, Danan M, Buisine A, et al. Elévation de la plombémie au cours de l'alcoolisme. Relation avec la pression artérielle. Presse Méd 1986;15:1227-9.

10 Moore MR, Meredith PA. The effect of carbon monoxide upon erythrocyte delta-aminolevulinic acid dehydratase activity. Arch Environ Health 1979;34:158-62.

11 Meredith PA, Moore MR. The in vivo effects of zinc on erythrocyte delta-aminolevulinic acid dehydratase in man. Int Arch Occup Environ Health 1980;45:163-8.

12 Telisman S, Kersanc A, Prpic-majic D. The relevance of arguments for excluding ALAD from the recommended biological limit values in occupational exposure to inorganic lead (WHO 1980). Int Arch Occup Environ Health 1982;50: 397-412.

13 Allain P, Mauras Y. Microméthode de dosage du plomb et du cadmium dans le sang et l'urine par absorption atomique au four graphite. Clin Chim Acta 1979;91:41-6.

14 Schmidt C. Lead determination in blood by atomic absorption spectroscopy. Am Ind Hyg Assoc J 1979;40:1085-90.

15 Grabecki J, Haduch T, Urbanowicz H. Die einfachen Bestimmungsmethoden der delta-Aminolävulinsäure im Harn. International Archivs Für Gewerbepathologie und Gewerbehygiene 1967;23:226-9.

16 Cardani A, Farina G. Influenza del consumo di bevande alcoliche sulle alterazioni della biosintesi dell'eme indotte dal piombo. Studio su 337 dipendenti di una fabbrica di accumulatori. Med Lav 1972;63:22-8.

Accepted 9 December 1991 